\title{
Capital Flow Management
}

\author{
By Olivier Jeanne*
}

Advanced economies have open capital accounts but there remains a wide variety in the capital account policies of emerging market and developing economies. Most emerging economies have adopted a regime of free capital account mobility, but some countries, such as Brazil have recently experimented with taxes on capital inflows. Other countries that are important players in the global economy, such as China, have traditionally controlled their capital flows very tightly and continue to do so.

This raises several questions. First, why do countries have so different ways of managing their capital accounts? Second, do the international spillovers associated with capital account policies warrant more international oversight or coordination than is now the case? It may seem surprising that unlike for international trade in goods, where the World Trade Organization offers a strong set of rules, there are no international rules for capital account policies. ${ }^{1}$ The rationale for government management of capital flows, and whether there is a need for international "rules of the game" for those policies, have been identified as important questions for the G20 discussions after the crisis, and the staff of the IMF has produced several analytical papers on those issues (IMF (2011), Ostry et al. (2011)).

The theoretical literature had little to say about those issues until recently. A few recent papers, however, have started to provide a more rigorous welfare-based analysis of the gains and costs of capital ac-

\footnotetext{
* Johns Hopkins University, Mergenthaler Hall 454, 3400 N. Charles Street, Baltimore MD 21218. Also affiliated with the Peterson Institute for International Economics (Washington DC), the NBER (Cambridge MA) and the CEPR (London UK). Email: ojeanne@jhu.edu. I thank the discussants, Kristin Forbes, Raghuram Rajan and André Sapir, as well as Anton Korinek and John Williamson for their comments on this paper.

${ }^{1}$ With some exceptions, such as the pre-requisite of capital mobility for European Union membership.
}

count restrictions for individual countries and for the rest of the world. This paper will present a brief and selective review of the lessons we have learnt from that literature.

\section{Light touch}

The global financial crisis of 2008 has been followed by a new wave of experimentation with prudential capital controls, with Brazil as the poster child. ${ }^{2}$ Brazil introduced a tax on all capital inflows except foreign direct investment in October 2009 , at a time when many emerging market economies were faced with a surge in capital inflows. In October 2010 the tax rate on debt inflows was raised to 6 percent, whereas that on inflows of portfolio equity remained at 2 percent. The tax was lowered recently as the surge in capital flows to emerging market countries abated, consistently with the tax's stated intention of smoothing out the boom-bust cycle in capital flows. It is too early to tell whether the Brazilian experience was a success, but there is evidence that the tax was effective, perhaps in part because the tax rate has remained relatively low.

Theoretical justification for such policies can be found in the new welfare economics of prudential capital controls, reviewed in Jeanne, Subramanian and Williamson (2011) and Korinek (2011b). This literature essentially transposes to international capital flows the closed-economy analysis of the macroprudential policies that aim to curb the boom-bust cycle in credit and asset prices. Frictions in the credit market lead to an amplification mechanism in which growth in credit and asset prices feed

\footnotetext{
${ }^{2}$ Taiwan, Korea, Indonesia and Thailand also introduced curbs on capital inflows in 2009 and 2010. Historically, emerging market economies have resorted to such capital controls before, with Chile as an important example until the late 1990s.
} 
on each other, positively in the boom and negatively in the bust. Individual agents tend to overborrow in the boom because they do not take into account the impact of their borrowing on aggregate systemic risk. Thus, it is optimal to impose a Pigouvian tax on debt inflows in the boom to reduce the risk and severity of the bust. ${ }^{3}$

The Brazilian capital controls are consistent with the main features of the optimal prudential tax implied by theory. First, the tax should be on capital inflows. Second, the tax should be countercyclical, i.e., it should be raised when there is surge of capital inflows and reduced when the pressure abates. Third, the tax should also be differentiated by type of inflow: the tax rate should be higher on the flows that are systemically more dangerous (such as short-term or foreign currency debt) than on portfolio equity flows or FDI (Korinek (2010)). The optimal tax, thus, happens to fall primarily on the types of capital flows that have not been found to have a significant positive effect on growth.

The optimal tax has been quantified in calibrated dynamic welfare optimizing models. Models with endogenous and occasionally binding constraints are not tractable and must be simplified in some respects to be solvable, even numerically, but the results may be informative. As a nice example of this approach is Bianchi (2011), who finds, in a model calibrated to Argentina, that the optimal tax rate on oneyear foreign currency debt increases with the country's indebtedness and fluctuates between 0 percent and a maximum of 22 percent.

\section{Heavy hand}

The capital account restrictions of many countries are much more intrusive than the optimal prudential controls described above. China, because of its importance

\footnotetext{
${ }^{3}$ Should those objectives be reached with domestic macroprudential regulation rather than capital controls? If the transactions that need to be taxed tend to take place between residents and nonresidents this is a semantic question. Furthermore, the reach of capital controls may be broader than that of macroprudential regulation if the latter is limited to the banking system.
}

in the global economy, is the most significant example. It would be an exaggeration to describe the Chinese capital account as closed, if only because China receives large amounts of FDI (and even encourages it through tax incentives). But China severely restricts other forms of capital inflows, and controls its outflows too. Most of the Chinese foreign assets are accumulated as international reserves, which the authorities have accumulated in large quantities.

Let us consider, as a stylized theoretical representation of this type of policy, a country that has "full control" over its capital flows, in the sense that it can determinedirectly or indirectly - the levels of capital inflows and outflows of various types. Then full control over capital flows implies full control over the trade balance and the real exchange rate. To see this, consider the simple case of a country in which financial flows are limited to FDI inflows and reserves accumulation. Assume that a given year, the authorities increase reserves by $\$ 1$ bn keeping FDI inflows unchanged. Then as a matter of accounting the current account and the trade balance must increase by the same amount (\$1bn). And the real exchange rate must, in equilibrium, be consistent with that trade balance. With full control over the capital account, the authorities can undervalue the real exchange rate and affect trade flows in the same way as they would with tariffs and subsidies on trade. Jeanne (2011) formalizes this simple argument in a model with tradable and nontradable goods and looks at the domestic implications of such a policy.

There can be a domestic welfare case for such a policy, in the same way as there was a welfare case for prudential capital controls. For example, it could be justified by learning-by-doing externalities in the tradable good sector (Rodrik (2008), Aizenman and Lee (2010)). The trade-off, in this case, is between the growth benefit of developing the tradable good sector and the valuation loss on the reserves that will be incurred when the domestic currency eventually appreciates. 


\section{Is there a need for international rules?}

There is a theoretical presumption that international cooperation is desirable for capital account policies for the same reason as it is desirable in the area of international trade. At an abstract level, capital controls are taxes on intertemporal trade between countries, and there is no reason to believe that they should be less of a collective concern than taxes on intratemporal trade, i.e., tariffs. Even when capital account restrictions are justified by a domestic externality (as discussed in the previous two sections), they have an impact on the rest of the world that needs to be taken into account. For example, Forbes et al. (2011) find that capital controls in Brazil caused investors to increase the share of their portfolios allocated to other Latin American countries, possibly shifting vulnerabilities from one country to another.

Unlike for trade policies, where the welfare benefits of international cooperation have been studied in a large literature, there has been relatively little research on the international coordination of capital account policies. Recent exceptions are Costinot, Lorenzoni and Werning (2011) and Korinek (2011a), and I am summarizing their main conclusions below.

On one hand, both papers point out that international cooperation is warranted if countries are large enough to influence their intertemporal terms of trade (the world real interest rate). In the two-country model of Costinot, Lorenzoni and Werning (2011), the country that borrows can raise its welfare relative to the laissez-faire level by imposing a tax on capital inflows, and lower in this way the interest rate that it must pay to the lending country. Conversely, the lending country will want to impose a tax on capital outflows in order to raise the world interest rate. The Nash equilibrium of this game leads to a Pareto inefficient "capital war" in which both countries see their welfare decreased. This is, essentially the transposition to intertemporal trade of the classical "optimal tariff" argument for free trade.
On the other hand, Korinek (2011a) shows that international cooperation is less justified if countries are small and use capital account restrictions to redress domestic externalities. The Nash equilibrium in this case may look like a capital war and lead to a decrease in the world real interest rate but it is Pareto efficient. The reason is that there is no true international externality: the spillovers that countries impose to each other are mediated through a price (the real interest rate) in a perfectly competitive market (the global capital market) so that the first welfare theorem applies to the decentralized equilibrium between countries. A coordinated reduction in capital account restrictions may be justified, however, if the restrictions involve deadweight administrative costs or induce circumvention effort.

Those papers make important inroads but important questions remain to be explored. In particular, it would be interesting to understand better how capital account policies interact in a Keynesian model of the global economy with insufficient global demand. Presumably, international cooperation might be justified to prevent a Nash equilibrium in which countries use capital account policies to implement beggar-thy-neighbor depreciations that boost domestic employment at the expense of foreign employment.

\section{Conclusion}

The international community invests considerably more effort in maintaining a level playing field for international trade in goods than for international trade in assets. This may be justified by the fact that the gains from free trade seem much larger for the former than for the latter (Bhagwati (1998)). However, capital account restrictions can be used to distort real exchange rates to the advantage of the countries that impose them, which contradicts the purpose of the trade rules and over time may erode the support for free trade. One could try to get the international community to agree to the appropriate levels or ranges for exchange rates, but given the difficulties involved in such an exercise, it would make 
sense to focus instead on the source of the distortions in domestic policies, in particular capital account policies.

Whence a case for introducing a dose of international oversight - or even international rules - over capital account policies, at least for the countries that are significant participants in the global trade system. Those rules should have a light touch and the goal should certainly not be free capital mobility, since at least some forms of capital controls might be justified to redress domestic externalities - and might do so without imposing significant negative externalities on the rest of the world. In Jeanne, Subramanian and Williamson (2011) we discuss and compare different approaches to international cooperation in this area, and propose - for the sake of transparency and as a way of limiting the potential harmthat capital controls be price-based and with a tax rate less than 15 percent.

More generally, capital account policies, defined in a broad sense (in particular, including public accumulation of foreign assets), touch on several issues at the core of the debates on reforming the international monetary system. Further research is needed to better understand the conditions under which the international spillovers from capital account policies warrant international coordination.

\section{REFERENCES}

Aizenman, Joshua, and Jaewoo Lee. 2010. "The Real Exchange Rate, Mercantilism and the Learning By Doing Externality." Pacific Economic Review, 15(3): 324-335.

Bhagwati, Jagdish. 1998. "The Capital Myth: the Difference between Trade in Goods and in Dollars." Foreign Affairs, 77(May/June): 7-12.

Bianchi, Javier. 2011. "Overborrowing and Systemic Externalities in the Business Cycle." American Economic Review, 101(7): 3400-3426.
Costinot, Arnaud, Guido Lorenzoni, and Ivan Werning. 2011. "A Theory of Optimal Capital Controls." Manuscript, MIT.

Forbes, Kristin, Marcel Fratzscher, Thomas Kostka, and Roland Straub. 2011. "Bubble Thy Neighbor: Direct and Spillover Effects of Capital Controls." Working Paper MIT.

IMF. 2011. "Recent Experiences in Managing Capital Inflows-Cross-Cutting Themes and Possible Policy Framework." http://www.imf.org/external/np/pp/eng/2011/021411a.

Jeanne, Olivier. 2011. "Capital Account Policies and the Real Exchange Rate." Manuscript, Johns Hopkins University.

Jeanne, Olivier, Arvind Subramanian, and John Williamson. 2011. "Who Needs to Open the Capital Account?" Forthcoming, Peterson Institute for International Economics.

Korinek, Anton. 2010. "Regulating Capital Flows to Emerging Markets: An Externality View." Manuscript, University of Maryland.

Korinek, Anton. 2011a. "Capital Controls and Currency Wars." Manuscript, University of Maryland.

Korinek, Anton. 2011b. "The New Economics of Prudential Capital Controls: A Research Agenda." IMF Economic Review, 59: 523-561.

Ostry, Jonathan D., Atish R. Ghosh, Karl Habermeier, Luc Laeven, Marcos Chamonand Mahvash S. Qureshi, and Annamaria Kokenyne. 2011. "Managing Capital Inflows: What Tools to Use?" IMF Staff Discussion Note, 11/06.

Rodrik, Dani. 2008. "The Real Exchange Rate and Economic Growth." Brookings Papers on Economic Activity, 2008(2): 365-412. 